\title{
Stultifera Navis
}

Paulo Abe

Num período remoto, quando o tempo era contado de outra forma que a de hoje e a terra ainda tinha uma forma totalmente distinta,

- Eles estão cortando todas as nossas árvores, ancião!

- Quem ousaria tirar nossa proteção contra os animais?! Como se chama o profanador patriarca dessa família?!

- Ancião, todos o chamam pelo nome de Noé.

\section{Stultifera Navis}

Todos cuspiram ao ouvir.

Essa era a reunião de todos os patriarcas de todas as famílias daquela região. A tenda improvisada entre grossas árvores protegia o cheiro dos homens de todos os animais noturnos e ainda não os deixava a vista, coisa que as árvores tinham o trabalho natural de o fazer.

A situação era crítica.

Todos cochichavam para os seus vizinhos naquele pequeno espaço:

- Nós não podemos deixar ele fazer o que quiser!

- Temos de impedi-lo! 
- Onde Noé está com a cabeça?!

- Silêncio, todos! - Interrompeu por fim o ancião. - Não é Noé o neto do grande Enoque?

- Sim. - Disse um dos patriarcas.

- Então, nós lhe devemos muito respeito. É contado desde minha infância que o grande Enoque subiu aos céus e nunca mais voltou.

- Sim, é verdade. Meu pai sempre me contou essa história. - Todos em uníssono disseram.

- Ele pode apenas ter fugido. - Disse um rapaz jovem.

- Menino... - O ancião começou. - As histórias de nossos antepassados devem ser respeitadas. Com certeza Noé tem uma boa razão para desmatar nossa querida floresta.

- O que faremos então, ancião?

- Acendam suas tochas, nós vamos nos encontrar com Noé!

Todos então passaram os galhos secos um para o outro. Acenderam cinquenta tochas e cinquenta homens começaram sua caminhada pela grossa floresta. Passo a passo na escuridão, apesar de saberem que o fogo tem o poder de afugentar os animais, os mais ferozes por vezes se aventuravam contra os homens.

No meio do caminho, alguns lobos começaram a fazer uma tela contra os cinquenta homens. Todos remexeram suas tochas, formando uma parede de chamas, faiscando suas vontades de seguir adiante. Depois de um tempo, as feras desistiram.

- É por isso que precisamos de nossas árvores! Olhe, ancião, aqui já há bem menos do que quando começamos nossa caminhada.

- Está de noite, meu caro. Talvez seja apenas uma impressão. Continuemos andando para tirar logo as dúvidas com Noé.

Alguns passos mais a multidão deu, quebrando tantos galhos e folhas secas que haviam pelo chão. Um chiado foi impossível não ouvir de tantos pés.

- Ei, vocês não acham que os lobos desistiram fácil demais? - Cochichou o mais jovem.

- É... agora que você falou... - Disse um outro também na orelha dele.

De repente uma tocha foi jogada para cima. Todos olharam lentamente o pequeno lume subir e descer numa explosão de faíscas até que então decidiram olhar para a origem da tocha. E, ao acenderem sua retaguarda, todos tremeram suas vozes em um duplo som:

- Ur-so...

O grupo começou a correr freneticamente. Alguns ainda jogaram suas tochas na direção do urso negro. Ele não parava seu trote ainda que avançando 
sobre quarenta e nove homens. Não demorou para uns tropeçarem, caírem e serem resgatados por colegas. $\mathrm{O}$ ancião, apesar de sua idade, já havia aperfeiçoado como correr na escuridão na densa floresta. Mas assim também o urso.

Não tardou para que o urso pesado os alcançasse. No entanto, ao fazê-lo sem causa conhecida, as chamas não mais iluminavam as árvores que, de certa forma, multiplicavam as tochas.

Não havia mais árvores.

O urso freou com todas as suas forças e regressou sem pensar duas vezes para a proteção de madeira e sombras.

À frente dos quarenta e nove homens, centenas de tochas iluminavam um amplo espaço plano. O ancião, mesmo com sua idade e experiência, nunca havia visto tal coisa em sua vida no meio de sua floresta.

- Meu Deus... aquilo é um barco?

Hesitantemente, todos rastejaram seus pés por aquele terreno desconhecido, descampado, sem folhas, raízes ou qualquer outra coisa que terra lisa e vermelha. A luminosidade aumentava quanto mais eles chegavam perto, até verem uma silhueta sombria a se esticar até seus pés. Todos se arrepiaram instantaneamente.

- Noé?! É você?!

- Sim. Ancião?

- Sim, sou eu.

- $\mathrm{O}$ que o traz com tantos homens a essa hora da noite à minha casa?

- Nós viemos conversar.

- Deve ser uma discussão muito importante então...

- E é mesmo, Noé! - Interrompeu o mais jovem.

Depois de fuzilar com os olhos o jovem, o ancião disse:

- O que nós queremos é saber o que o está levando a desmatar a nossa floresta.

- Eu imaginei que viriam até aqui. Vos explicarei, mas primeiro sigam- me. Sejam bem-vindos.

Todos andaram desconfiadamente entre as tochas acesas e sobre uma rampa que levava até o interior daquela nave fora de lugar. Os quarenta e nove se agarravam, como que procurando forças de seus vizinhos. Mas ao adentrarem por completo, toda e qualquer coragem foi simplesmente dizimada.

O som de inúmeros animais ecoou naquela noite como uma sinfonia bestial. Tantos animais se debatendo em jaulas e alguns ainda à solta congelaram até o espírito dos mais velhos. Uma cobra aqui, ratos ali... e até mesmo um tigre.

- Ma-mas o que significa isso, Noé? 
- Eu recebi um chamado de Deus.

Aquela frase fez todos darem uma pausa de qualquer coisa que estivessem sentindo. Aquele momento era excepcional, como as histórias de Enoque que seus avós contavam. Essa seria a história dessa geração.

Até os animais silenciaram.

- E o que Deus vos disse, Noé?

- Deus me convocou para uma missão.

- E que missão seria essa?!

- Ela consiste em salvar todos os animais e humanos para a geração futura de uma grande catástrofe.

- Todos?!

- Sim. Todos.

As risadas foram inevitáveis. Cuspes foram jogados ao chão pelo absurdo.

- Calem-se!!! - Protestou o próprio ancião. - Mas, Noé, você sabe que todos os animais não caberão aqui dentro!

- Deus há de prover.

- "Deus há de prover"?

- Sim.

Todos se reuniram em um canto daquela grande sala para cochichar em cumplicidade longe dos ouvidos do capitão do navio.

- Ele só pode estar louco. - Disse um.

- Ele não pode pegar todos os animais, nem se pudesse. Afinal, alguns são nosso principal alimento! - Argumentou outro, mostrando as palmas da mão.

- Ele está velho, já tem seiscentos anos. Talvez nem saiba mais o que fala.

- Mas ele parece resoluto.

- O que faremos então?

- O matamos... - disse pronto o mais jovem.

- Matar?! Está louco?! Mesmo que seja outro Deus que ele adore, qualquer Deus é contra o assassinato!

- Mas então o que faremos ancião? - Outro pôs as mãos sobre a cabeça.

- Vamos questioná-lo ainda mais profundamente.

Todos se espalharam novamente e rodearam o calmo Noé.

- Noé, nos diga. Por que Deus iria fazer isso conosco? Me refiro a tal catástrofe.

- Os pecados devem ser limpados da terra, ancião.

- E como ele o fará? Um barco o ajudará?

- Sim, pois Ele fará chover durante cento e cinquenta dias e noites.

Um breve momento de silêncio se fez e, na falta de entendimento, outra rajada de gargalhadas ecoou pela escuridão noturna, o que foi disputado pelos 
mugidos, latidos, granidos etc. dos outros animais. Todos cuspiram novamente pelo absurdo.

- Mas, Noé, nunca choveu mais de dois dias seguidos nessas terras. Tal fato de cento e cinquenta não se conta nem desde os tempos de Adão.

- Agora será a marcação de um novo tempo, ancião.

Aquela calma perturbava e muito a todos ali contra Noé. No entanto, todas as suas ideias eram realmente escandalosas a qualquer ouvido de um homem. Quantos delírios possuía aquele construtor de barcos no meio de uma floresta!

Todos se reuniram novamente em segredo no canto do gigante barco. E todos esperavam alguém começar a próxima discussão. Mas ela não veio. A iniciativa não tomou os espíritos daqueles homens. Logo, eles voltaram seus olhos para o ancião, que recolheu absolutamente os seus de seus companheiros para uma desolação introspectiva:

- Eu não acredito que Deus enviaria uma catástrofe para nos destruir. - Resmungou entre sua longa barba o ancião, meio que para e si e para os outros.

- Nem Adão foi morto! Nem Caim!

A decepção tomou o coração de todos vagarosamente. E a desesperança reverberava o sino obtuso do fim.

- Eu tenho um plano...

Imediatamente todos procuraram a fonte da voz.

- Mas o meu plano parte da ideia de que tudo isso é uma loucura, uma desrazão. - As sobrancelhas grossas dos que estavam ali se levantaram silenciosamente.

- Deus nunca nos destruiria! Noé está louco e devemos garantir que sua loucura não prejudique nossas famílias. - Sua voz começou a aumentar de volume e resolução.

- Pois, nós somos os patriarcas e protegeremos nossa floresta e nossas famílias!

O ancião tentou dizer algo, mas foi engolido por seus próprios homens.

- SIM!!!

- Então, larguemos esse barco de loucos e coloquemos o plano em prática!

- Meu pai era construtor e me ensinou toda a sua arte. - Começou o mais jovem.

- Convenci hoje de manhã Noé de que as fundações estão já muito fortes. Mas ele não se convenceu de que tinha todos os animais, então iria continuar desmatando até ter mais que suficiente para os animais.

- Mas então o que faremos? 
- Nós vamos lhes dar um casal de cada animal. Assim, eles vão poder reproduzir e não desfalcará nossa subsistência. Tirando o fato de que seria muito difícil levar ursos, tigres e leões para a barca de Noé em grande quantidade. - Todos ouviam sentados ao jovem patriarca enquanto o ancião ficava imóvel, encostado em uma parede com os braços cruzados.

- Mas para isso precisaremos usar nossas próprias armas. - O jovem então colocou as mãos sobre os ombros do ancião, que levantou lentamente seu olhar. - Usaremos nosso gado. Peguem os touros! Afugentaremos os animais para o navio daquele louco!

- SIM!!!

Uma vez localizados os animais que faltavam à grande barca, bastava ordenar o ancião que manejassem os touros para andarem de modo a espantar o que estivesse no caminho. Claro que por vezes os touros fugiam e acabavam por virar presas. Mas em suma, tudo ia de acordo com o que o tão jovem patriarca havia pensado.

- Tantos touros pisando assim no solo estão acabando por destruir a vegetação. Veja, acabaram de derrubar uma árvore. - Alertou, preocupado o ancião.

- Vejam só, todos! O nosso ancião não está disposto a fazer alguns sacrifícios para proteger nossas famílias! - O jovem novamente atiçou a questão.

Uma horda de cuspes foi dada pelos quarenta e oito patriarcas. Cabisbaixo, o ancião continuou a guiar os seus touros em silêncio e com pesar.

Logo depois de um mês, todos os animais foram enviados à nau de Noé. Todos estavam felizes com suas ações com exceção do ancião. Foi possível acalmar Noé e sua ideia louca de Deus destruir o mundo e a raça humana a cada dia se provava mais fantasmagórico.

- Olá, patriarcas, agora é chegada a hora! Enquanto entram aqui neste navio as últimas cobras, venho aqui vos convidar para se juntar a mim e à minha família neste último resquício de segurança para o novo renascer da humanidade. Claro que vocês têm de discutir um pouco, portanto tomem seu tempo, mas, por favor, não se demorem. Tenham fé.

Todos imediatamente se reuniram abaixo da rampa para o barco, mas o ancião ficou para olhar para o céu e meditar a tal catástrofe que arrebataria todos os homens da face da terra. Quando sua imaginação se desvencilhou da razão, pôde criar em sua mente o cenário diluvial que estaria por vir. Por segundos, ficou em uma dicotomia entre maravilhado e aterrorizado. O céu estava com nuvens e quando o sol achou uma brecha para os olhos do ancião, uma verdade mística aproveitou o caminho aberto para os outros olhos do ancião, que embranqueceram. 
Confiar o louco aos marinheiros é com certeza evitar que ele ficasse vagando indefinidamente entre os muros da cidade, é ter a certeza de que ele irá para longe, é torná-lo prisioneiro de sua própria partida. Mas a isso a água acrescenta a massa obscura de seus próprios valores: ela leva embora, mas faz mais que isso, ela purifica. Além do mais, a navegação entrega o homem à incerteza da sorte: nela, cada um é convidado ao seu próprio destino, todo embarque é, potencialmente, o último. É para o outro mundo que ele chega quando desembarca. Esta navegação do louco é simultaneamente a divisão rigorosa e a Passagem absoluta. Num certo sentido, ela não faz mais que desenvolver, ao longo de uma geografia semirreal, semi-imaginária, a situação liminar do louco no horizonte das preocupações do homem medieval - situação simbólica e realizada ao mesmo tempo pelo privilégio que se dá ao louco de ser fechado às portas da cidade: sua expulsão deve encerrá-lo; se ele não pode e não deve ter outra prisão que o próprio limiar, seguram-no no lugar de passagem. Ele é colocado no interior do exterior, e inversamente. Postura altamente simbólica e que permanecerá sem dúvida a sua até nossos dias, se admitirmos que aquilo que outrora foi fortaleza visível da ordem tornou-se agora castelo de nossa consciência.

A água e a navegação têm realmente esse papel. Fechado no navio, de onde não se escapa, o louco é entregue ao rio de mil braços, ao mar de mil caminhos, a essa grande incerteza exterior a tudo. É um prisioneiro no meio da mais livre, da mais aberta das estradas: solidamente acorrentado à infinita encruzilhada. É o Passageiro por excelência, isto é, o prisioneiro de passagem. E a terra à qual aportará não é conhecida, assim como não se sabe, quando desembarca, de que terra vem. Sua única verdade e sua única pátria são essa extensão estéril entre duas terras que não lhe podem pertencer ${ }^{\mathrm{I}}$.

Todos os quarenta e oito olharam o ancião respectivamente com surpresa, pavor e desprezo. Eles cuspiram por aquele absurdo.

- A loucura tomou também o ancião!

Instintivamente, aqueles patriarcas arrastaram os seus pés para trás como numa espécie de barreira do mal. As palavras afiadas e úmidas avançavam enquanto seus corpos recuavam. Mas quando o jovem patriarca se percebeu entre aqueles com o coração reinado pelas trevas do medo, imediatamente parou, teve vergonha de si, no entanto, antes de ficar rubro, o ódio lhe expelia dos pulmões em outra direção.

I FOUGAULT, Michel. A história da loucura. São Paulo: Editora Perspectiva, 2008, p. I2. 
- O que vocês estão fazendo?! Rápido, peguem o ancião e o ponham dentro da barca!!! - O derradeiro exílio havia sido declarado. Mas ninguém respondeu. É certo que pensavam suas reações quase incontroláveis, mas se viram sem saída, em um paradoxo, e quando covardes estão em tal situação, a mudança de espírito é a última de suas opções. - Vamos, se mexam!!! - E parados ficaram.

Com toda a sua força, o jovem patriarca arrastou o ancião em transe para dentro do barco. Sentiu-se, por cada segundo que o segurava, como se fosse infectado por tal doença moral. E, uma vez no interior, o jovem fechou à tranca a passagem.

- Pronto, seus covardes! - Disse o jovem lá de cima. - Salvei nossas famílias! Eu!

Porém, seu olhar de orgulho e ira rapidamente se transformou.

Lá de cima, pôde testemunhar em primeira mão a revolta dos touros pelo seu mestre contra toda a floresta.

Árvore por árvore em meio a um nevoeiro de pó, destroços e ruína foi sendo derrubada, a última proteção.

Nem outro absurdo volveria o jovem à sanidade de sua alma que já orbitava seu corpo.

"Alguém cuspiu em mim?!"

Mas houve tal tentativa.

Olhou sem vida seus homens e ninguém o encarava.

"Não pode ser. Ninguém está acima de mim."

Então, como os outros estavam, olhou para o céu negro.

E um segundo cuspe lhe atingiu.

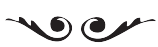

Paulo Abe - Graduado em Filosofia pela Universidade de São Paulo em 2013.

pauloaltro@gmail.com 